\title{
Modelling of Health Risk Associated with the Intake of Pesticides from Romanian Fruits and Vegetables
}

\author{
Mariana Minut ${ }^{1}$, Mihaela Roșca ${ }^{1}$, Raluca-Maria Hlihor ${ }^{1,2}{ }^{-1}$, Petronela Cozma ${ }^{1, *}$ (i) and \\ Maria Gavrilescu 1,3,* \\ 1 Department of Environmental Engineering and Management, "Cristofor Simionescu” Faculty of Chemical \\ Engineering and Environmental Protection, "Gheorghe Asachi” Technical University of Iasi, \\ 73 Prof. D. Mangeron Blvd, 700050 Iasi, Romania; minut.mariana@yahoo.com (M.M.); \\ roscamihaela23@yahoo.com (M.R.); raluca.hlihor@uaiasi.ro (R.-M.H.) \\ 2 Department of Horticultural Technologies, Faculty of Horticulture, “Ion Ionescu de la Brad" University \\ of Agricultural Sciences and Veterinary Medicine of Iasi, 3 Mihail Sadoveanu Alley, 700490 Iasi, Romania \\ 3 Academy of Romanian Scientists, 3 Ilfov Street, 050044 Bucharest, Romania \\ * Correspondence: petronela_cozma@tuiasi.ro (P.C.); mgav@tuiasi.ro (M.G.)
}

Received: 9 September 2020; Accepted: 28 November 2020; Published: 1 December 2020

\begin{abstract}
This study is focused on the assessment of risks caused by pesticide residues to Romanian and other European populations, by modelling the acute and chronic risks considering short- and long-term exposures to pesticide residues in specific fruits and vegetables from different Romanian regions. Data were obtained from the Romanian 2016 official monitoring programme. For assessing the dietary risk, we used the Pesticide Residue Intake model-PRIMo. According to the official data, it was found that $50.44 \%$ of fruit samples and $28.25 \%$ of vegetable samples were contaminated with pesticides. Our study focused on acute risks and chronic risks (in a maximalist worst-case scenario) posed by pesticide residues in strawberries, apples, lettuce and potatoes, given both their high degree of consumption and contamination with pesticides. The short-term exposure assessment of children's health due to consumption of apples, lettuce and potatoes contaminated with dimethoate, chlorothalonil and carbendazim, revealed exposure levels higher than the acute reference dose $(A R f D$, as $100 \%)$, raising acute risks. On the other hand, the long-term exposure assessment showed that the highest percentage from the acceptable daily intake (ADI, as $100 \%)$ was obtained for German children (DE child) (273.9\%), followed by Netherlands children (NL child) (143.7\%) diets, based on consumption of apples with dimethoate residues. Therefore, serious measures are needed for banning pesticides such as dimethoate, chlorothalonil and carbendazim from all countries in the EU. This would reduce the health risks generated by the consumption of contaminated fruits and vegetables.
\end{abstract}

Keywords: fruits and vegetables; pesticides residues; PRIMo model; short-term and long-term exposures; WHO cluster diets

\section{Introduction}

The rapid development of chemical and agrochemical industry has led to the discharge of large amounts of chemical compounds in the environment. Since the middle of the last century, there was a considerable increase of pesticides use in agriculture, causing toxic effects on all living beings [1-4].

Worldwide, the total amount of pesticides (herbicides, fungicides and insecticides) has been estimated at $3.3 \times 10^{6} \mathrm{t} /$ year, China being the largest consumer of pesticides with an amount of $1.8 \times 10^{6} \mathrm{t} /$ year, while at the European level, approximately $0.42 \times 10^{6} \mathrm{t} /$ year of pesticides have been used [5,6]. In Romania, the statistical data retrieved from 1990 to 2014 showed a decrease of pesticides 
use, from 250,000 tons of pesticides of active ingredients to approximately 8000 tons [7]. It was estimated that the production of fruits, vegetables and cereals will drop by $78 \%, 54 \%$ and $32 \%$, respectively, if proper amounts of pesticides are not applied for crop protection [8].

People can be exposed to pesticides by different pathways, including inhalation, dermal contact or food consumption. Since large amounts of fruits and vegetables from human diets are consumed either raw or semi-processed, there is a possibility to contain higher levels of pesticides residues than other food commodities [9-11]. Moreover, fresh fruits and vegetables are usually also consumed to prevent different diseases such as cancer, cardiovascular diseases and obesity. Therefore, the consumption of at least five portions of fruits and vegetables per day is strongly encouraged [12].

Although plant protection is indispensable for obtaining good quality products and in sufficient quantities to satisfy all food needs, the use of pesticides for crop protection is leading to adverse effects for the environment (water, soil and air) and human health [9,13-15]. Exposure to pesticides may cause both acute (short-term exposure) and chronic (long-term exposure) effects. The acute effects are generally associated with headaches, abdominal pain, vomiting, coma, difficulty in breathing. The chronic effects include certain types of cancer, damage to immunological and reproductive system, or neurological toxicity. Children are particularly the most vulnerable category of the population exposed to pesticides effects. For children, pesticides can induce neurodevelopment and neurobehavioral effects, birth defects, asthma, and cancer (Table A1 in Appendix A). Moreover, a child's diet is quite different from that of adults, since children may ingest a larger amount of food per body weight, starting from breast milk, which may be contaminated.

Despite the fact that different authorized agricultural practices are developed, as well as programmes or restrictions in the use of pesticides, they are still applied in an unsafe manner $[9,16,17]$. Nowadays, the monitoring of pesticide residues in fruits and vegetables is a priority in many countries.

Studies developed up to now are very useful in drawing attention from a risk/benefit perspective in relation with the preventive effect of contaminated food consumption [18-20]. For example, Chen et al. [21] analyzed 3009 samples of fruit and vegetables from 5 different districts of Xiamen City. A number of 1135 samples contained residues of pesticides as cypermethrin (18.7\%), chlorpyrifos (7.3\%), triadimefon, dichlorvos, omethoate and chlorothalonil (4.1-1.6\%). The results obtained from the assessment of human health risks showed that the hazard quotient (HQ) ranged from $0.01 \%$ for fruits, to $2.61 \%$ for vegetables. Bakirci et al. [22] revealed that, from 1423 samples (of which 573 were fruit samples and 850 were vegetables samples) collected from the Aegean region of Turkey, 885 samples had residues of pesticides. The highest amounts of residues were represented by chlorpyriphos, acetamiprid and carbendazim. Lozowicka et al. [12], in a study developed in Poland considering 392 fruit samples, observed that $48.2 \%$ of the collected samples did not contain pesticides residues, while $45.9 \%$ of samples contained residues of pesticides at/or below the MRLs (Maximum Residue Levels). Also, $5.9 \%$ of samples contained residues of pesticides above the MRL. The majority of pesticides residues were detected in apples and sour cherries.

The present study is also supported by the production, import and export of specific fruits and vegetables in 2016 and 2017, in Romania (Table 1). In this sense, it is important to assess risks not only for the Romanian population, but also for the European population. In our view, it is possible that this scenario may occur with risks to human health. It is of major importance to assess risks not only considering data related to pesticide residues from local grown food, but also from both the imported and exported ones. Reporting the risk assessment from the present study at the European level would contribute to a better understanding of risks caused by imported fruits and vegetables with pesticide residues. 
Table 1. Production, import and export of fruits and vegetables in 2016 and 2017 in Romania [23].

\begin{tabular}{ccccc}
\hline Year & $\begin{array}{c}\text { Apples } \\
\text { (tons) }\end{array}$ & $\begin{array}{c}\text { Strawberries } \\
\text { (tons) }\end{array}$ & $\begin{array}{c}\text { Lettuce } \\
\text { (tons) }\end{array}$ & $\begin{array}{c}\text { Potatoes } \\
\text { (tons) }\end{array}$ \\
\hline \multirow{5}{*}{$\begin{array}{c}\text { Import } \\
2016\end{array}$} & 116,740 & 6497 & 11,941 & 164,758 \\
2017 & 114,177 & 6564 & 13,556 & 137,383 \\
& & Export & & \\
2016 & 6620 & 7 & 43 & 2346 \\
2017 & 6562 & 162 & 52 & 20,398 \\
& & Production & & \\
2016 & 467,259 & 23,000 & 3402 & $2,689,733$ \\
2017 & 348,656 & 27,050 & 3609 & $3,116,912$ \\
\hline
\end{tabular}

In this framework, the main objective of the present study is focused on the evaluation of the acute and chronic health risks associated with the intake of pesticides residues from fruits and vegetables for the Romanian and other European populations, by modelling the short- and long-term exposures to pesticide residues in fruits and vegetables from the Romanian regions. Chronic risks are assessed in a maximalist worst-case scenario given the maximum concentration uptake and no processing factors. The potential human health exposure to pesticides within the proposed scenario was assessed by modelling the data collected from the Romanian Report on the National Plan for Pesticide Residues Monitoring in Fruit, Vegetables and Cereals, using the European Food Safety Authority (EFSA) PRIMo model, a European validated risk analysis model.

\section{Materials and Methods}

\subsection{Data Collection}

The data related to residues of pesticides in fruits and vegetables were obtained from the Report on the National Plan for Pesticide Residues Monitoring in Fruit, Vegetables and Cereals elaborated by the National Phytosanitary Authority, Romania, according to the official annual surveillance [24]. In Romania, three Competent Authorities are involved in elaboration and implementation of the National Control Programme for pesticide residues: National Sanitary Veterinary and Food Safety Authority (NSVFSA), Ministry of Agriculture and Rural Development (MARD) and Ministry of Health $(\mathrm{MH})$. Further, implementation of the monitoring programme is performed by MARD through the Laboratory for Pesticides Residues Control in Plants and Vegetable Products and Zonal Laboratory for Pesticides Residues determination in Plants and Vegetables Products-Mures, which analyzes the samples taken by Counties and Bucharest Phytosanitary Units. In 2016, a total number of samples of 343 for fruits and 683 for vegetables were analyzed in the Central Laboratory for the Control of Pesticide Residues in Plants and Vegetable Products in Bucharest, Romania. In the case of fruits, 50.44\% of samples were identified with residues of pesticides such as tebuconazole, carbendazim, boscalid, iprodione (in apples, strawberries, apricots, cherries, table grapes, peaches). In the case of vegetables, $28.25 \%$ of samples were identified with residues of pesticides such as iprodione, chlorothalonil, carbendazim (in lettuce, peppers, carrots, tomatoes, radishes, potatoes). From 57 samples of apples which were analyzed, residues of pesticides (one or more) were identified in 40 samples. Regarding strawberries, from a total of 28 samples, 17 of them contained pesticide residues. For lettuce, from an initial number of 51 samples, 35 samples were detected with one or more pesticide residues (Figure 1). From 54 samples of potatoes, 10 samples contained residues of pesticides [24]. 


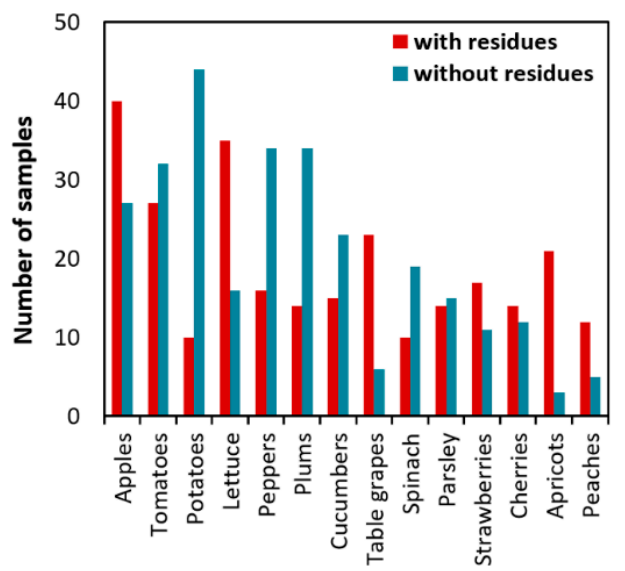

Figure 1. Residues of pesticides in samples of fruit and vegetables at the Romanian level in 2016 [24].

In addition, according to the National Phytosanitary Authority report [24], of the 343 fruits samples which were analyzed within the Central Laboratory for the Control of Pesticide Residues in Plants and Vegetable Products in Bucharest, a number of 167 samples contained residues below the EU Maximum Residue Levels (MRLs) and 6 samples (a strawberry sample, a peach sample and 4 apple samples) contained pesticide residues above the MRL. Of the 683 vegetables samples, 193 samples contained pesticide residues: for 186 samples, the values of pesticide residues were below the $M R L$, and 7 samples (one parsley leaf sample, one potato sample, and 5 lettuce samples) contained pesticide residues above the $M R L$.

On the other hand, according to the 2016 European Union Report on Pesticide Residues in Food [25], pesticides identified in samples of fruits and vegetables were: boscalid, captan, fludioxonil, tebuconazole, cyprodinil, azoxystrobin (found in apples, strawberries, peaches) and tebuconazole, boscalid, bromide ion, acetamiprid (found in lettuce, tomatoes, leek, head cabbage), respectively. From 1680 samples of apples, a number of 1066 samples were identified with one or more residues of pesticides, while from 1206 samples of strawberries, 933 samples contained one or more types of pesticide residues [25] (Figure 2).

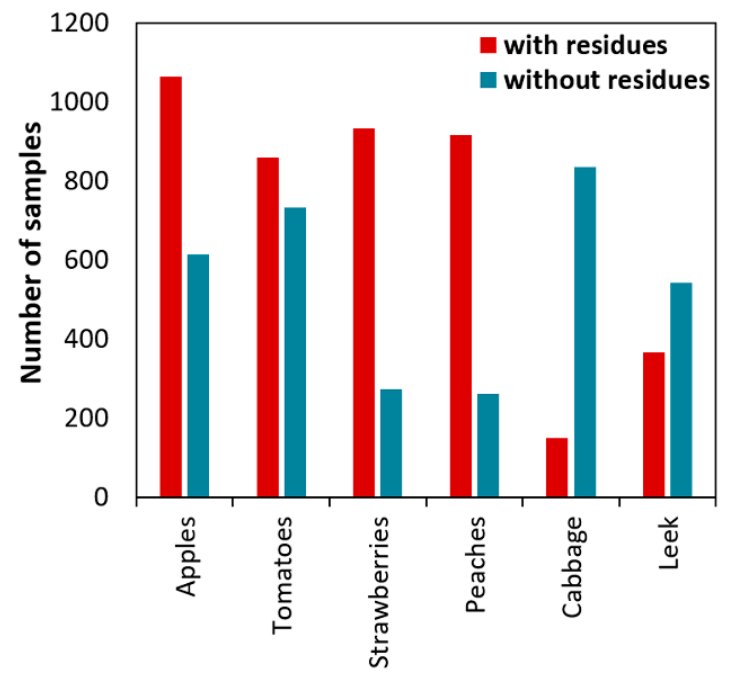

Figure 2. Residues of pesticides in samples of fruit and vegetables at the European level in 2016 [25].

All the samples were analyzed within national accredited laboratories based on standard methods. The analytical methods used are multi-residual methods (Gas chromatography-mass spectrometry-GC-MS and liquid chromatography-mass spectrometry-LC-MS) validated within the laboratory. The analysis methods within laboratory are residual methods validated in the Bucharest 
laboratory unit. The gas chromatographic method (GS-MS) was developed and validated on 186 active substances on three matrices according to European requirements. The liquid chromatographic method (LC-MS) was developed on 62 active substances. The multi-residual methods GS-MS and LC-MS were accredited in 2006 in accordance with the quality requirements of the ISO 17025 standard. Annually, the results are further reported to EU programmes and a National Summary report is published in the EFSA Journal [26]. Fruit and vegetables samples were taken from warehouses, shops, markets, supermarkets and manufacturer deposits from different Romanian regions. For our study, we selected only the areas where the samples were identified with more than one type of pesticide residue, and especially those exceeding the MRLs. The counties considered within the study are from the North-Eastern part of Romania (Iasi County) and South of Romania (Dâmbovița, Olt, and Vâlcea Counties).

\subsection{Human Health Risk Assessment}

\subsubsection{Model}

To assess human health risk posed by the presence of pesticide residues in fruits and vegetables, we used the second revision of the Pesticide Residue Intake model—PRIMo developed by the European Food Safety Authority in 2006 [27]. We proposed modelling the chronic risks to human health in a maximalist worst-case scenario which considers the data collected and reported by the National Plan for Pesticide Residues Monitoring in Fruit, Vegetables and Cereals, Romania, since these data report only to the maximum concentration of pesticide residues. At the national level, Romania has no official data on unit weights of fruits and vegetables or data on a large portion for children and adults. The considered scenario is closely related to other studies from literature [28,29].

The main purpose of PRIMo model is to estimate the short-term and long-term exposures of consumers to pesticide residues and to compare the estimated exposures with the toxicological reference values in order to identify the potential health risks. Another objective of this model is to carry out risk assessments in a standardized mode, necessary for regulatory issues at the EU level. PRIMo is a very flexible model, allowing for example, quantitative assessment of scenarios for nonstandard risks. The model also provides information to perform the risk assessment [27]. Our study was carried out in relation to short- and long-term exposures to pesticide residues by different population categories (kids/toddler, children, adults, all population, general population) from EU countries according to EFSA guidance [27]. For the exposure calculations, we took into account the deterministic approach, which implies the consideration of the highest residue level found in a vegetable product combined with the 97.5th percentile intake. We further assumed the worst-case scenario, where it is considered that all the chosen categories of Romanian vegetable products are exported and then consumed within the entire EU, while no processing factors were considered (EU countries which are available in the EFSA PRIMo model based on consumption estimates).

The EFSA PRIMo model calculates the short-term and long-term dietary exposures, accepting consumption at the 97.5 th percentile. Food consumption data, 97.5 th percentile consumption, highest available large portion (LP) and unit weights were retrieved from the national food surveys of the European Union Member States (Table 2) [27]. Depending on the unit weight of products, variability factors of $1,3,5,7$ or 10 were considered. The variability factor is an important parameter for risk assessment of acute intake of pesticide residues since it reflects differences between intakes. For case 1, PRIMo model includes a variability factor of 1 due to the fact that variability is not relevant for commodities. Variability factors of 5 and 7 were used in the estimates performed for cases 2a and $2 \mathrm{~b}$ (a variability factor of 7 is applied when the unit weight is between $25 \mathrm{~g}$ and $250 \mathrm{~g}$ and a variability factor of 5 is applied when the unit weight is $>250 \mathrm{~g}$ ) [30]. 
Table 2. Modelling parameters for short-term dietary exposure assessment [27].

\begin{tabular}{|c|c|c|c|c|c|c|c|c|c|c|c|c|c|}
\hline \multirow[t]{2}{*}{$\begin{array}{l}\text { Fruit and } \\
\text { Vegetables }\end{array}$} & \multirow[t]{2}{*}{ Pesticides } & \multicolumn{2}{|c|}{ Country } & \multicolumn{2}{|c|}{$\begin{array}{l}\text { Maximum Food } \\
\text { Intake (g/kg bw) }\end{array}$} & \multicolumn{2}{|c|}{ Body Weight (kg) } & \multicolumn{2}{|c|}{$\begin{array}{l}\text { Large Portion } \\
\text { (g/Person) }\end{array}$} & \multicolumn{2}{|c|}{ Unit Weight (g) } & \multirow[t]{2}{*}{ Case } & \multirow[t]{2}{*}{$\begin{array}{c}\text { Variability } \\
\text { Factor }\end{array}$} \\
\hline & & $\mathrm{C}$ & A & $\mathrm{C}$ & $\mathbf{A}$ & $\mathrm{C}$ & A & $\mathrm{C}$ & A & $\mathrm{C}$ & A & & \\
\hline Strawberries & $\begin{array}{l}\text { Tebuconazole } \\
\text { Dimethoate } \\
\text { Azoxystrobin } \\
\text { Propiconazole } \\
\text { Chlorothalonil } \\
\text { Penconazole } \\
\text { Tebuconazole }\end{array}$ & $\mathrm{DE}$ & NL & 15.59 & 5.29 & 16.15 & 63 & 251.8 & 333 & - & - & 1 & 1 \\
\hline Apples & $\begin{array}{l}\text { Dimethoate } \\
\text { Carbendazim }\end{array}$ & $\begin{array}{l}\text { UK } \\
\text { infants }\end{array}$ & LT & 20.72 & 11.14 & 8.7 & 70 & 180.3 & 780 & 112 & 131.8 & $2 a$ & 7 \\
\hline Lettuce & $\begin{array}{l}\text { Chlorothalonil } \\
\text { Tebuconazole } \\
\text { Iprodione }\end{array}$ & $\mathrm{DE}$ & UK Veg & 5.38 & 2.2 & 16.15 & 66.7 & 86.9 & 146.6 & 534.7 & 558 & $2 \mathrm{~b}$ & 5 \\
\hline Potatoes & $\begin{array}{l}\text { Carbendazim } \\
\text { Thiophanate-methyl } \\
\text { Chlorpyrifos-methyl }\end{array}$ & $\begin{array}{c}\text { UK } \\
\text { infants }\end{array}$ & UK Veg & 21.97 & 10.41 & 8.7 & 66.7 & 191.1 & 694.4 & 216 & 216 & $2 b / 2 a$ & 7 \\
\hline
\end{tabular}

C: children; A: adults; UK Veg: United Kingdom (UK) vegetarians. 
The calculations were also performed taking into account four categories of diets (B, D, E, F) from 13 dietetic categories established by the World Health Organization, covering 183 countries, including Romania [31]. Romania fits to Diet D along with Bulgaria, Moldova Albania, Armenia, Azerbaijan, Georgia, Belarus, Bosnia and Herzegovina, Iran, Kazakhstan, Kyrgyzstan, Montenegro, the Russian Federation, Serbia, Tajikistan. Diet B includes the following countries: Italy, Spain, Portugal, Cyprus, Greece, Israel, Lebanon, Turkey, the United Arab Emirates, Republic of North Macedonia, Turkmenistan, Ukraine, Uzbekistan. Diet E considers France, Germany, Austria, Poland, Belgium, Croatia, the Czech Republic, Denmark, Hungary, Ireland, Luxembourg, Malta, Netherlands, Slovakia, Slovenia, Switzerland, the United Kingdom of Great Britain and Northern Ireland. Diet F includes Estonia, Norway, Finland, Iceland, Lithuania, Latvia, Sweden. The WHO Regional EU diet is related to the European food consumption database at the regional level. In Table 3, the consumption for each category of food related to B, D, E and F diets is presented [32].

Table 3. Consumption cluster diets [32].

\begin{tabular}{ccccc}
\hline Consumption Cluster Diet & $\begin{array}{c}\text { Cluster B } \\
\text { (g/day) }\end{array}$ & $\begin{array}{c}\text { Cluster D } \\
\text { (g/day) }\end{array}$ & $\begin{array}{c}\text { Cluster E } \\
\text { (g/day) }\end{array}$ & $\begin{array}{c}\text { Cluster F } \\
\text { (g/day) }\end{array}$ \\
\hline Total cereals & 713.9 & 504.5 & 365.2 & 328.7 \\
Total roots and tubers & 245.7 & 243.6 & 277.4 & 204.7 \\
Total pulses & 62.9 & 36.8 & 49.4 & 47.9 \\
Total sugars and honey & 164.0 & 76.5 & 120.4 & 103.5 \\
Total nuts and oilseeds & 91.9 & 55.5 & 69.2 & 51.3 \\
Total vegetable oils and fats & 67.7 & 31.6 & 34.8 & 25.3 \\
Total stimulants & 18.6 & 4.9 & 22.3 & 24.1 \\
Total spices & 1.1 & 0.9 & 1.8 & 1.1 \\
Total vegetables & 524.8 & 266.8 & 248.6 & 196.5 \\
Total fish and seafood & 67.2 & 22.6 & 30.4 & 49.4 \\
Total eggs & 29.7 & 24.5 & 37.8 & 27.4 \\
Total fruits & 462.8 & 191.8 & 348.2 & 219.2 \\
Total milk and milk products & 190.6 & 302.6 & 179.6 & 237.9 \\
Total meat and offals & 189.8 & 91.0 & 163.5 & 166.4 \\
Total animal oils and fats & 11.2 & 6.8 & 15.7 & 8.2 \\
Total beverages & 161.0 & 81.5 & 312.5 & 187.0 \\
Total diet in grams per & 3002.9 & 1941.9 & 2276.8 & 1878.6 \\
person per day & & & & \\
\hline
\end{tabular}

\subsubsection{Acute Exposure Modelling}

For acute exposure, the model presents four different situations for calculation of the International Estimate of Short-Term Intake (IESTI). Each situation has a specific mathematical method, depending on the unit weights of the commodity. For strawberries, we considered case 1 , in which the residue concentration in sample corresponds more or less with the residue related to a portion of strawberries. The unit weight of a portion is less than $25 \mathrm{~g}$ (Equation (1)) [30]:

$$
\text { IESTI }=[L P \times H R] / b w
$$

where: $L P=$ highest available large portion $(\mathrm{kg} /$ day); $H R=$ highest residue level in composite samples of the edible portion, found in the residue trials $(\mathrm{mg} / \mathrm{kg}) ; b w=$ body weight $(\mathrm{kg})$.

For apples, we applied case $2 \mathrm{a}$, where a portion may contain a higher residue compared to composite sample, i.e., when unit weight is more than $25 \mathrm{~g}$. A variability factor $(v)$ of 7 is introduced. The weight of the unit of the product is less than the weight of the large portion ( $L P)$ (Equation (2)) [30]:

$$
I E S T I=[\{U \times H R \times v\}+\{(L P-U) \times H R] / b w
$$

where: $U=$ unit weight $(\mathrm{g}) ; v=$ variability factor. 
For lettuce, we considered case $2 b$, where the unit weight of the product is higher than the weight of the large portion (Equation (3)). A variability factor (v) of 5 is introduced [30]:

$$
I E S T I=L P \times H R \times v / b w
$$

For potatoes, we considered case $2 \mathrm{a}$ for adults (Equation (5)), and case $2 \mathrm{~b}$ for children (Equation (6)). In this case, a variability factor $(v)$ of 7 is introduced [27].

The exposures calculated for the highest measured residue were expressed as a percentage of ARfD (Equation (4)):

$$
\% A R f D=I E S T I / A R f D \times 100
$$

\subsubsection{Chronic Exposure Modelling}

Considering chronic exposure, human health risks are calculated by multiplying the concentration of residues of pesticides (all the vegetable products have residue levels equivalent to the MRLs) with a daily consumption of fruits and vegetables. For this scenario (maximalist worst-case scenario), we considered that all the fruits and vegetables were treated with pesticides, so as the level of residues did not exceed the maximum residues levels and all products are consumed unprocessed (raw), basically no processing factors are included. This scenario considers the estimation of the Theoretical Maximum Daily Dose (TMDI) within the evaluation (Equation (5)) [30]:

$$
T M D I=\sum M R L i \times F i
$$

where: $M R L i=$ Maximum Residue Level in a certain product $(\mathrm{mg} / \mathrm{kg}) ; F i=$ corresponding national consumption of the product (kg/day).

If TMDI exceeds the value of $A D I$, then IEDI (International Estimated Daily Intake) is calculated (Equation (6)) [30]:

$$
I E D I=\sum S T M R i \times E i \times P i \times F i
$$

where: $S T M R i=$ supervised trial median residue level of a certain product $(\mathrm{mg} / \mathrm{kg}) ; E i=$ factor for the edible apart of the particular product; $P i=$ processing factor of the particular product; $F i=$ corresponding national consumption of the particular product per person $(\mathrm{kg} / \mathrm{day})$.

The exposures calculated for the largest measured residue are expressed as a percentage of ADI (Equation (7)) [30]:

$$
\% A D I=[T M D I /(A D I \times 100)] \times 100
$$

The results of both short- and long-term exposure assessments are expressed as a percentage of ARfD or $A D I$, as follows: (i) if the values expressed as $\% A R f D$ and $\% A D I$ are $<100 \%$, then the pesticide residues do not present a risk to human health; (ii) if the values expressed as $\% A R f D$ and $\% A D I$ are $>100 \%$, then the pesticide residues pose a risk to human health $[3,27]$.

\section{Results}

\subsection{Pesticide Residues}

Up to six residues of pesticides were found in the selected fruits (strawberries, apples) and vegetables (lettuce, potatoes), most of them being fungicides. In strawberries, six pesticides were identified (chlorothalonil, dimethoate, penconazole, propiconazole, tebuconazole and azoxystrobin), of which tebuconazole, chlorothalonil and propiconazole exceeded MRLs. In apples, we identified specific concentrations for two pesticides, dimethoate and carbendazim, both overtaking the MRLs. The following pesticides were detected in lettuce: chlorothalonil, with high MRL overtaking, iprodione with a relatively low $M R L$ overtaking, and tebuconazole. In the case of potatoes, 
three pesticides were identified: carbendazim, thiophanate-methyl and chlorpyrifos-methyl, all of them overtaking the MRLs (Table 4).

Table 4. Pesticide residues detected in the selected fruits and vegetables.

\begin{tabular}{|c|c|c|c|c|c|}
\hline $\begin{array}{l}\text { Fruits and } \\
\text { Vegetables }\end{array}$ & Pesticides & $\begin{array}{c}\text { Residues of } \\
\text { Pesticides }^{1}(\mathrm{mg} / \mathrm{kg})\end{array}$ & $\begin{array}{l}M R L s^{2} \\
(\mathrm{mg} / \mathrm{kg})\end{array}$ & $\begin{array}{c}A R f D^{2} \\
(\mathrm{mg} / \mathrm{kg} / \mathrm{body})\end{array}$ & $\begin{array}{c}A D I^{2} \\
\left(\mathrm{mg} / \mathrm{kg} / \text { body }^{2} \text { day }\right)\end{array}$ \\
\hline \multirow{7}{*}{ Strawberries } & Tebuconazole & 0.183 & $0.02 *$ & 0.03 & 0.03 \\
\hline & Dimethoate ${ }^{* *}$ & 0.432 & $0.01 *$ & 0.02 & 0.002 \\
\hline & & & & not applicable; & \\
\hline & Azoxystrobin & 0.122 & 10 & $\begin{array}{l}A D I \text { was } \\
\text { Sonsidered }\end{array}$ & 0.2 \\
\hline & Propiconazole ${ }^{* *}$ & 0.037 & $0.01 *$ & 0.1 & 0.04 \\
\hline & Chlorothalonil ** & 0.43 & 4 & 0.05 & 0.015 \\
\hline & Penconazole & 0.021 & 0.5 & 0.5 & 0.03 \\
\hline \multirow{2}{*}{ Apples } & Dimethoate ${ }^{* *}$ & 0.454 & 0.01 * & 0.02 & 0.002 \\
\hline & Carbendazim & 0.253 & 0.2 & 0.02 & 0.02 \\
\hline \multirow{3}{*}{ Lettuce } & Chlorothalonil ** & 15.435 & $0.01 *$ & 0.05 & 0.015 \\
\hline & Tebuconazole & 0.018 & 0.5 & 0.03 & 0.03 \\
\hline & Iprodione & 0.118 & $0.01 *$ & 0.06 & 0.02 \\
\hline \multirow{3}{*}{ Potatoes } & Carbendazim ${ }^{* * *}$ & 1.241 & $0.1^{*}$ & 0.02 & 0.02 \\
\hline & Thiophanate-methyl & 1.377 & 0.1 * & 0.2 & 0.08 \\
\hline & Chlorpyrifos-methyl ** & 0.021 & $0.01 *$ & 0.1 & 0.01 \\
\hline
\end{tabular}

${ }^{1}$ [24]; ${ }^{2}$ [33]; * Indicates lower limit of analytical determination; ${ }^{* *}$ not approved-withdrawal authorizations by 2019, max. period of grace: February-May 2020; ${ }^{* * *}$ not approved-max. period of grace: 31 May 2016.

The concentration of pesticides found in fruits and vegetables was initially compared to $M R L$, since it is the level established by authorities for pesticide monitoring. On the other side, according to the methodology of assessing human health risks, we also took into consideration the acute reference dose $(A R f D)$ for short-term risks, as well as the acceptable daily intake $(A D I)$ for long-term risks. The toxicological values were considered for each pesticide according to the EU Pesticides database [33] (Table 4).

\subsection{Assessment of Acute Exposure}

Figure 3 illustrates the results obtained considering the acute exposure of the Romanian and other European populations to the identified pesticide residues from different Romanian regions, expressed as $\% A R f D$ for strawberries (Figure 3a), apples (Figure 3b), lettuce (Figure 3c) and potatoes (Figure 3d).

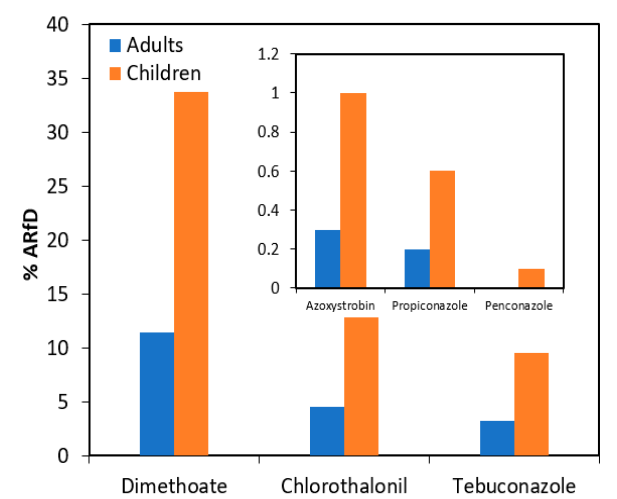

(a)

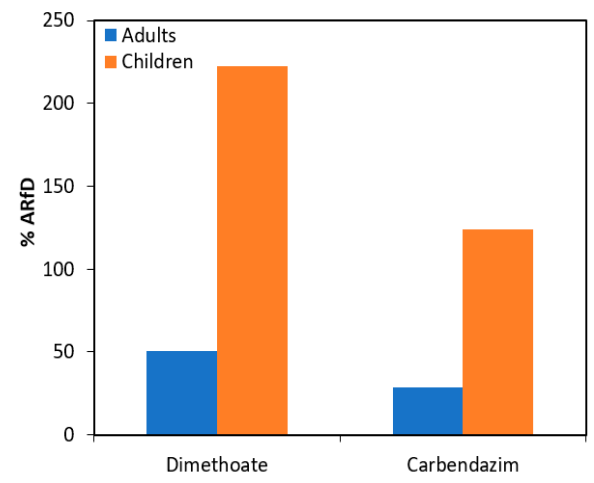

(b)

Figure 3. Cont. 


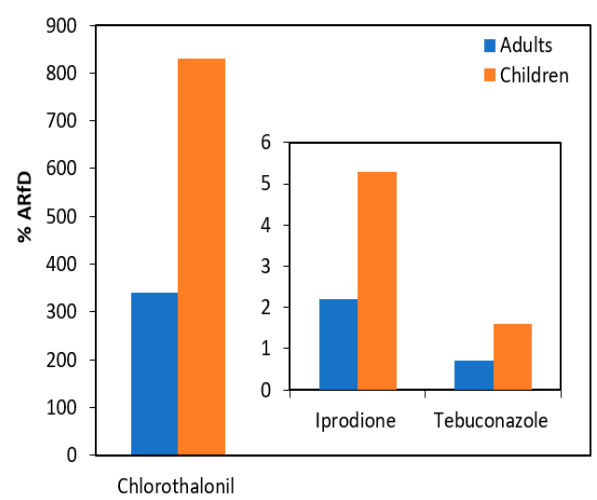

(c)

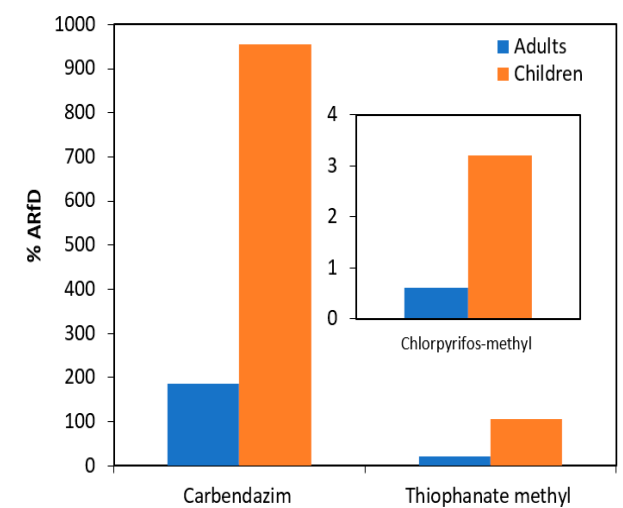

(d)

Figure 3. Acute exposure of the population to pesticide residues from fruits and vegetables from the Romanian regions, expressed as \%ARfD: strawberries (a), apples (b), lettuce (c) and potatoes (d).

In the first instance, we observed that the presence of residues in strawberries does not pose an acute risk for adults and children, which are the categories of consumers selected within our study (Figure 3a). However, even if the identified pesticides do not exceed ARfD (taken as 100\%), there is an exception related to the presence of dimethoate in strawberries, since the resulted level of exposure is higher than the level obtained in other cases. Dimethoate residues reach $33.7 \%$ of $A R f D$ for children, and $11.4 \%$ of $A R f D$ for adults. Further, the presence of dimethoate detected in apples at a concentration of $0.454 \mathrm{mg} / \mathrm{kg}$ (MRLs is $0.01 \mathrm{mg} / \mathrm{kg}$ ) poses a risk to human health when the acute exposure of children is considered, since this represents $222.4 \%$ of $A R f D$ (Figure $3 \mathrm{~b}$ ). A similar situation was found for apples containing carbendazim residues at a concentration of $0.253 \mathrm{mg} / \mathrm{kg}$ (MRLs is $0.02 \mathrm{mg} / \mathrm{kg}$ ), which can result in an acute risk for children (123.9\% of ARfD) (Figure 3b). In the case of lettuce containing chlorothalonil at a concentration of $15.435 \mathrm{mg} / \mathrm{kg}$, we observed that the \%ARfD is much higher than $100 \%$, specifically $339.2 \%$ for adults and $830.5 \%$ for children, respectively (Figure 3c). Further, the consumption of potatoes containing carbendazim residues at a concentration of $1.241 \mathrm{mg} / \mathrm{kg}$ (MRLs is $0.1 \mathrm{mg} / \mathrm{kg}$ ) can generate acute risks for both children and adults (954.1\% of ARfD and $185.2 \%$ of $A R f D$, respectively). We also observed that the presence of thiophanate-methyl in potatoes at a concentration of $1.377 \mathrm{mg} / \mathrm{kg}$ (MRLs of $0.1 \mathrm{mg} / \mathrm{kg}$ ) can generate acute risks for children $(105.9 \%$ of $A R f D$ ) (Figure 3d). The presence of other pesticides in all the fruits and vegetables included in this study and having much lower ARfD values than $100 \%$, suggests that there are no implications for human health from this point of view.

\subsection{Assessment of Chronic Exposure}

Figure 4 shows the chronic exposure results for the European population to the identified pesticide residues in strawberries, apples, lettuce and potatoes, expressed as $\% A D I$. Considering the long-term exposure, we observed that dimethoate residues in apples are exceeding $100 \%$ of $A D I$ for children (273.9\% in the case of DE child and $143.7 \%$ for NL child, respectively). Similar to the acute exposure assessment, we observed that the presence of residues in the analyzed fruits and vegetables, does not pose a chronic risk for any of the consumers considered within the study. However, even if the thresholds for other pesticides were not exceeded, some concerns could be raised regarding the presence of dimethoate in strawberries, chlorothalonil in lettuce and carbendazim in potatoes (Figure 4). 


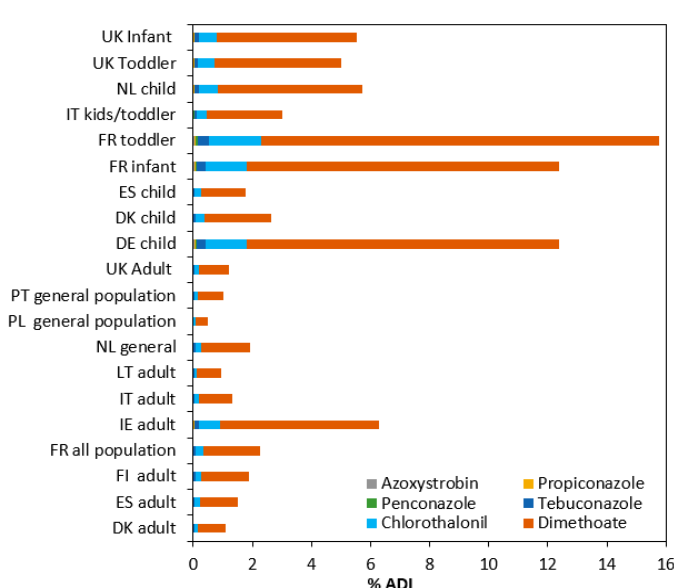

(a)

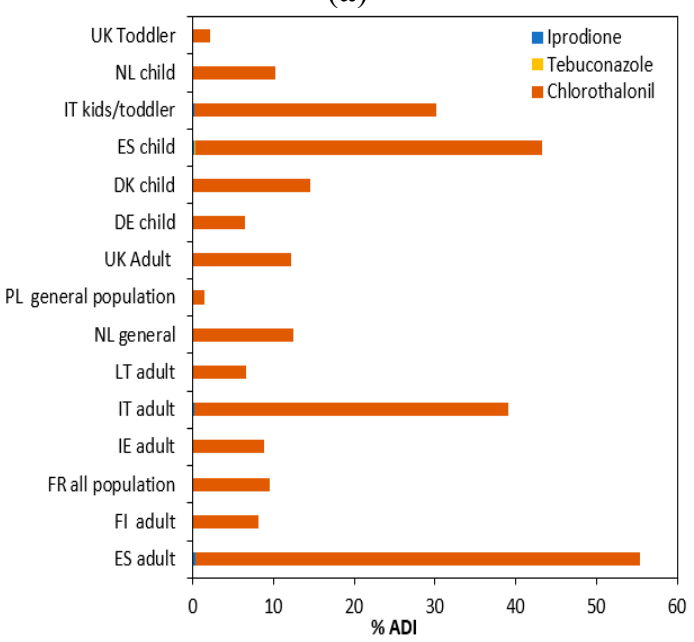

(c)

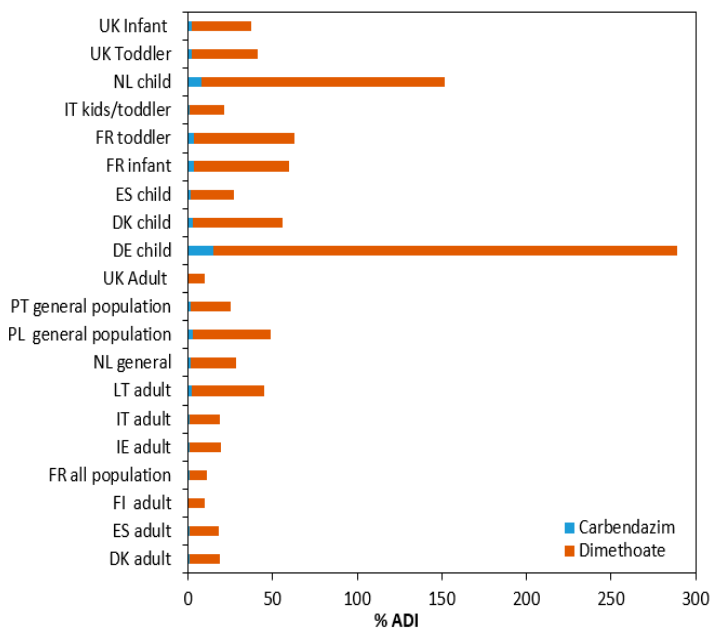

(b)

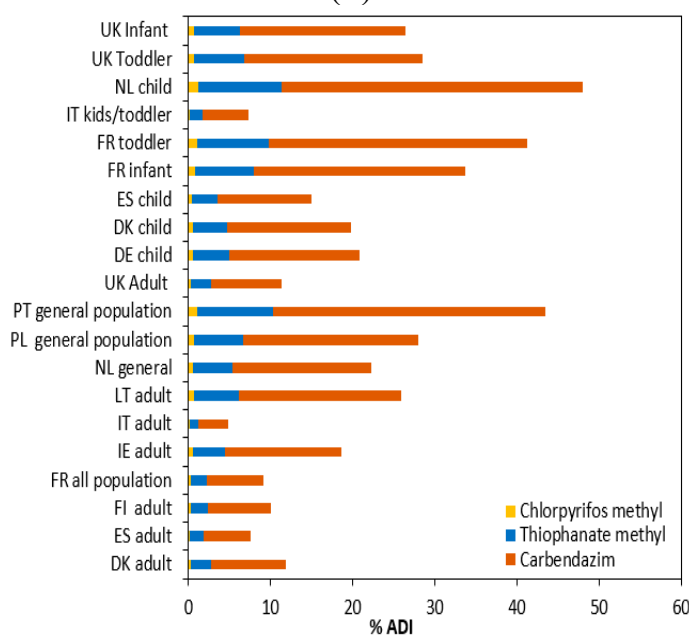

(d)

Figure 4. Chronic exposure of the population to pesticide residues from fruits and vegetables from the Romanian regions, expressed as \%ADI: strawberries (a), apples (b), lettuce (c) and potatoes (d) (DK child—Denmark: children; DK adult—Denmark: adult; ES child—Spain: children; ES adult-Spain: adult; FI adult-Finland: adult; FR infant-France: infant; FR toddler-France: toddler; FR all population-France: all population; IT kids/toddler-Italy: kids/toddler; IE adult-Ireland: adult; IT adult-Italy: adult; LT adult-Lithuania: adult; NL child-Netherlands: children; NL general-Netherlands: general; PL general population-Poland: general population; PT general population-Portugal: general population; UK Toddler-United Kingdom of Great Britain: Toddler; UK Infant-United Kingdom of Great Britain: Infant; UK Adult-United Kingdom of Great Britain: Adult).

In terms of chronic risk assessment for groups of countries with similar diets (Figure 5), the main categories of population exposed to dimethoate residues from strawberries are: the population included in the WHO Regional EU diet $(1.87 \%$ of $A D I)$ and the one included in the WHO cluster diet E $(1.9 \%$ of $A D I)$. Looking at Figure $5 \mathrm{~b}$, we can observe that, due to consumption of apples containing dimethoate, the most affected population is the one included in the WHO Cluster Diet $\mathrm{B}(22.9 \%$ of $A D I)$, followed by the WHO Cluster Diet E (19.2\% of $A D I)$, the WHO Regional European $\operatorname{diet}(15.1 \%$ of $A D I)$ and the WHO Cluster Diet D (15.09\% of $A D I)$. Population included in the WHO Regional EU diet (38.7\% of $A D I)$ and WHO cluster diet $\mathrm{B}(36.8 \%$ of $A D I)$ are the most affected due to consumption of lettuce containing chlorothalonil. Representative for consumption of potatoes containing carbendazim residues is the population included in the WHO cluster diet D (25.1\% of $A D I)$, followed by the WHO Regional EU diet $(24.9 \%$ of $A D I)$ (Figure 5 ). 


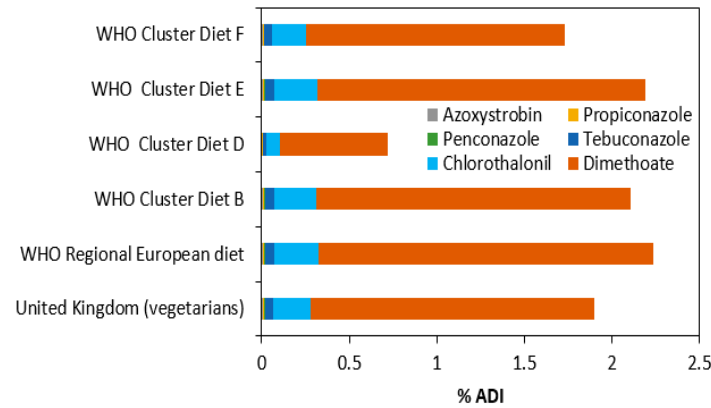

(a)

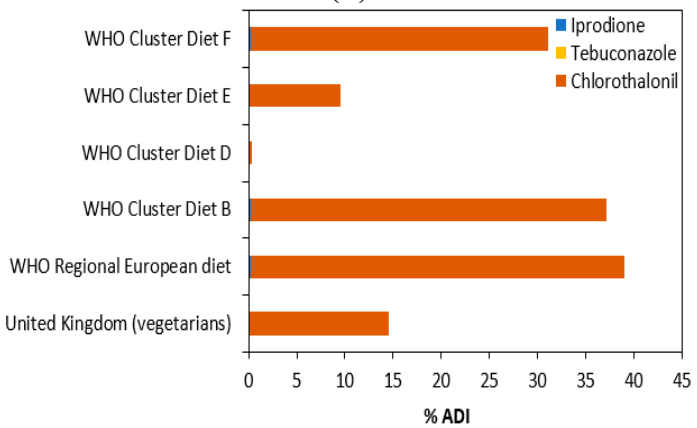

(c)

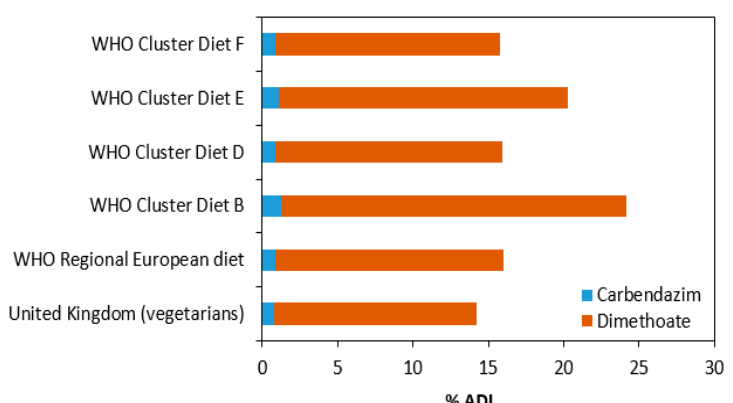

(b)

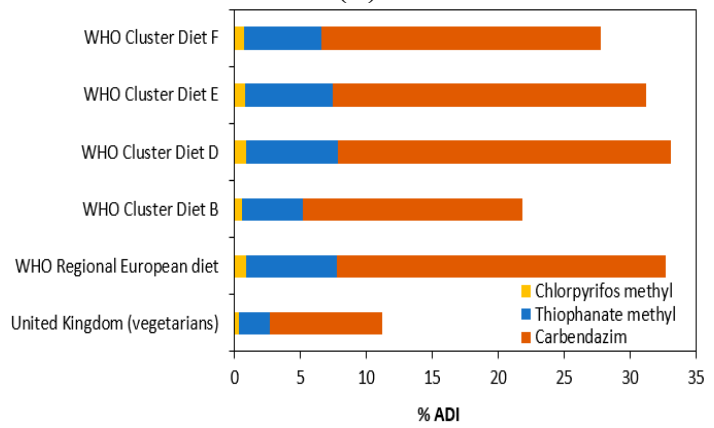

(d)

Figure 5. Chronic exposure for groups of countries with similar diets according to WHO clusters: strawberries (a), apples (b), lettuce (c) and potatoes (d).

\section{Discussion}

According to the results detailed above, the assessment of the short-term exposure of children to pesticides showed that the consumption of apples, lettuce and potatoes contaminated with dimethoate, chlorothalonil and carbendazim, respectively, results in a much higher percentage than ARfD taken as $100 \%$, generating acute health risks. The long-term exposure assessment showed that the highest percentage of $A D I$ resulted in the case of apples consumption containing dimethoate residues, for DE child $(273.9 \%)$ followed by NL child $(143.7 \%)$. Romanian population's health, which is included in the WHO cluster diet $\mathrm{D}$, could be affected over the long term by the consumption of apples containing dimethoate and potatoes containing carbendazim. As in the other cases, for countries with similar diets, the long-term risk is acceptable, since the \%ADI is lower than 100.

Considering that we proposed the evaluation of health risks in a maximalist worst-case scenario for chronic exposure, it means that the possibility of population consuming the 97.5th percentile intake value during a long period of their life (chronic exposure) is very small.

Based on our results and those from literature, we can summarize that the risk to human health caused by the presence of pesticides in fruits and vegetables depends on different factors such as: pesticides types, concentration of pesticide residues in samples, the type of exposure (acute or chronic), the type of diet adopted by various socio-human categories, and finally, age of the investigated group category. It should be noted that all of these factors may vary from country to country. Some common results highlighted that consumption of fruits and vegetables with pesticide residues are mainly causing toxicity to children, the long-term risk in the majority of cases being acceptable, while possible acute health risk to consumers (especially to children) were observed by the majority of researchers [34].

For example, Szpyrka et al. [35] performed an analysis regarding pesticide residues in fruits and vegetables from the southeastern region in Poland. The authors highlighted that the exposure of consumers from Poland related to pesticide residues in food did not raise health concerns (for both acute and chronic exposure). However, the higher percentages than the reference of long-term exposure were associated with dimethoate pesticide found in apples (a value of $6.8 \%$ of $A D I$ was obtained for children, and $1.7 \%$ of $A D I$ for adults, respectively). In line with the results of Szpyrka et al. [35], a risk 
assessment study performed in Kazakhstan by Lozowicka et al. [36] showed that the pesticide residues detected in tomatoes and cucumbers did not constitute a risk for Kazakh people in spite of multiple samples exceeding the MRLs, also containing residues and metabolites of illegal pesticides.

On the other hand, Lozowicka [29], when evaluating the health risk generated by the presence of pesticides in apples from northeastern and central Poland, found that children were the most vulnerable category of population. Representative results regarding the risk associated with the presence of pesticides residues in apples were obtained for dimethoate, with a value of $312 \%$ of ARfD, followed by chlorpyrifos methyl (104\% of $A R f D)$, and tebuconazole (173\% of $A R f D)$. A risk assessment study of pesticide residues in Chinese pears performed by Li et al. [34] showed a potential acute risk for children generated by the presence of bifenthrin. Struciński et al. [37] concluded that chronic exposure related to pesticide residues present in different fruits and vegetables available on the Polish market was lower than the toxicological reference values. Mebdoua et al. [38] provided important results addressing the consumers from Algeria, regarding the short- and long-term risk assessment associated with the presence of chlorpyrifos in apples and potatoes. In the case of apples, the values of short-term exposure were $558 \%$ of $A R f D$ for children and $237.8 \%$ of $A R f D$ for adults. A relatively lower exposure was obtained considering the consumption of potatoes, for adults ( $6.5 \%$ of $A R f D)$ compared to children (19.4\% of $A R f D)$. No chronic risk was observed and, in most cases, pesticide exposure was below $1 \%$ of $A D I$. Knežević et al. [28] provided an interesting study on risk assessment of pesticides intake in the Croatian diet. The authors analyzed a total of 866 samples of 28 different types of fresh fruits and vegetables from domestic production and import. Samples were evaluated as part of the Croatian Monitoring Programme on pesticide residues, considering the official 2007-2009 surveillance data. For long-term exposure, no health risk concerns were obtained.

On the contrary, for short-term exposure, a potential risk for children was identified associated with 8 pesticide residues ( $>150 \%$ of $A R f D$ ) and for the adult population, considering 3 pesticide combinations ( $>150 \%$ of $A R f D$ ). For example, the analysis of short-term risk exposure to chlorpyrifos in potatoes and lettuce showed the following values: for children, $32 \%$ of ARfD in potatoes, and $11.6 \%$ of ARfD in lettuce, while for adults, $10 \%$ and $5 \%$ of $A R f D$, respectively. However, the highest exceedance of the toxicological reference values occurred for procymidone in lettuce [28]. Struciński et al. [37] performed a risk assessment associated with dietary intake in vegetables, fruits and other food products from the Polish market, considering both chronic and acute exposure. Potential exceedance of the toxicological reference values was examined in the case of short-term exposure scenario for chlormequat in pears ( $425 \%$ of $A R f D$ for children and $100.2 \%$ of $A R f D$ for adults) and for carbendazim in lettuce (76.7\% of ARfD for children, and $31.3 \%$ of ARfD for adults). In the case of chronic exposure, most of the estimated daily intakes were below $1 \%$ of the respective $A D I$ values. For example, considering UK adults and GEMS/Food Cluster E consumption data, the \%ADI were above $1 \%$ for chlorpyrifos in oranges/mandarins and imazalil in grapefruit, bananas, and oranges/mandarins. For German children consumption, a value of $7 \%$ from $A D I$ was found for pesticides chlorpyrifos and imazalil in oranges/mandarins. A similar pattern was observed by Stephenson and Harris [39] in their study on dietary exposure to glyphosate in crop production. The UK toddler group was the most exposed category of population.

According to our findings, special attention should be given to the exposure of children and the adult population to dimethoate, chlorothalonil and carbendazim. This is also justified by the fact that, at this point, these pesticides are no longer approved at the EU level. In addition, the consequences that these pesticides generate for human health and the environment should be also considered. Dimethoate, an organophosphate insecticide, introduced in 1950 and used to kill insects and mites, proved to be one of the most controversial pesticides, and this must be taken into account carefully, since it acts as an acetyl cholinesterase inhibitor, which may cause negative effects on the development and reproduction of human system, and also generates long-term effects on aquatic species. The European Commission published Regulation (EU) 2019/1090 in accordance with the Regulation EC 1107/2009, which banned the use of dimethoate at the level of EU [40,41]. In 2016, France was the first country which banned 
the use of dimethoate, followed by Spain and Italy. Another pesticide, carbendazim, was banned in the USA, Australia and also in the majority of EU countries due to its high toxicity and persistency. Carbendazim is a fungicide used for controlling fungal diseases in fruits and cereals. However, this pesticide is a major pollutant detectable in food, water and soil and classified as possible human carcinogen. This fungicide has negative effects on human health, aquatic and terrestrial organisms and is no longer approved since 2016. Chlorothalonil, a fungicide that is no longer approved for use in EU countries since 2019 [42], tends not to be persistent in soil, but may be persistent in water. It has a low mammalian toxicity, but there is some concern regarding its bioaccumulation potential. Chlorothalonil is moderately toxic to birds, honeybees and earthworms and more toxic to aquatic organisms. Other pesticides that have attracted the attention of specialists due to their toxic effects are chlorpyrifos-methyl and propiconazole, banned since 2016 and respectively, 2019 (Tables A1 and A3 in Appendix A).

\section{Conclusions}

Our study showed that, according to the 2016 official surveillance programme in Romania, $50.44 \%$ of fruits collected from different Romanian regions contained more than one pesticide residue (such as tebuconazole, carbendazim, boscalid, iprodione, cyprodinil, fludioxonil). Similarly, $28.26 \%$ of the examined vegetable samples were identified with pesticide residues (such as iprodione, chlorothalonil, carbendazim, boscalid, chlorpyrifos). This study was limited to a few commonly consumed fruits and vegetables, mainly selected on the basis of their higher degree of contamination. Moreover, for Romania, there are no official data on maximum food intakes $(\mathrm{g} / \mathrm{kg} \mathrm{bw}$ ) or on the large portion for children and adults, necessary to calculate the acute and chronic risks for specific population. For chronic exposure, the study considers the maximalist worst-case scenario, since the available data from the official surveillance are related only to the maximum concentration of pesticide residues. The most relevant conclusions which can be drawn based on the proposed scenario within our study are as follows:

(1) The results demonstrate that, in general, the pesticide residues found in the examined fruits and vegetables do not pose high risks to human health based on short-term (acute) and long-term (chronic) exposures. However, there are some situations where thresholds have been exceeded. For example, the presence of dimethoate detected in apples poses risks to children health, in both acute and chronic exposures. A similar situation was found for apples containing carbendazim, which resulted in an acute risk for children. In the case of lettuce containing chlorothalonil, it was observed that the \%ARfD is much higher than $100 \%$ for both adults and children. Further, the consumption of potatoes containing carbendazim residues generates an acute risk for adults and children, while the presence of thiophanate-methyl in potatoes generates an acute risk for children.

(2) The study reveals that dimethoate residues in apples exceeded the $100 \%$ ADI for both DE child and NL child diets for long-term exposure, while the highest $\% A D I$ resulted for population included in the WHO cluster diet B. In other cases, even considering the worst-case scenario, the long-term exposure data concluded to acceptable risks. The children from Germany and France toddlers are the main category of population exposed to dimethoate residues in strawberries, while the population related to Regional European diet faces the highest long-term exposure and potential for human health risks. Adults and children from Spain are the most exposed categories due to the consumption of contaminated lettuce, while the population included in the Regional European diet and the WHO cluster diet B is the most exposed to dimethoate. The children from The Netherlands, the population from Portugal and the one included in the WHO cluster diet $\mathrm{D}$ (of which Romania is taking part) are representative for consumption of potatoes containing pesticide residues. These findings indicate that risk exposures to dietary intake may vary from country to country and/or from diet to diet. 
(3) Our results are very pertinent, since they describe risks for the Romanian and other European population posed by the presence of pesticide residues in different categories of fruits and vegetables. Moreover, our study shows significant results since there is a lack of scientific works in literature describing the level of contamination of main fruits and vegetables produced and consumed in Romania and at the European level, given their export. This study can be a basis for development of preventive action to reduce human health risk and for monitoring the residues of pesticides, both in fruits and vegetables, and as an extension, in crops on agricultural lands. The governments could regulate the use of some active substances and implement special agricultural policies and working procedures with benefits to human health. Moreover, dietary modification by consuming organic products may reduce the exposure to pesticide residues. Since different commodities samples taken from warehouses, shops, markets, supermarkets and manufacturer deposits from specific Romanian regions were detected with pesticide residues exceeding MRLs values, more strict measures should be taken by the authorities (penalties against the local producers or imposing the necessity of retailers to present a certificate of pesticide residue analysis).

(4) Based on our research, the human health risk assessment represents a strong evidence to support a ban on several pesticides such as dimethoate, chlorothalonil and carbendazim from Romania and other countries which still allow their use. In spite that these pesticides are not approved by the EU, they are still not banned in all the EU countries. In our opinion, the necessity for human health risk assessment is a priority in the national and international contexts, since these analyses are very scarce in various cases.

Author Contributions: Conceptualization, M.G., M.M., M.R. and R.-M.H.; methodology, M.M., M.R. and R.-M.H.; formal Analysis, M.M., M.R.; writing—original draft preparation, M.M., M.R., P.C.; writing—review and editing, R.-M.H., P.C., M.G.; supervision, M.R., P.C., M.G.; funding acquisition, M.G., R.-M.H. All authors have read and agreed to the published version of the manuscript.

Funding: This research was funded by two grants of the Romanian National Authority for Scientific Research, CNCS -UEFISCDI, project number PN-III-P4-ID-PCE-2016-0683, Contract No. 65/2017, project number PN-III-P2-2.1-PED-2016-1662, Contract No. 10PED/2017 and project number PN-III-P2-2.1-PED-2019-5239, Contract 269PED/2020.

Conflicts of Interest: The authors declare no conflict of interest. The funders had no role in the design of the study; in the collection, analyses, or interpretation of data; in the writing of the manuscript, or in the decision to publish the results.

\section{Appendix A}

Table A1. Chronic effects associated with pesticides exposure [43-45].

\begin{tabular}{|c|c|c|}
\hline Chronic Effects & Children & Adults \\
\hline Carcinogenic effects & $\begin{array}{l}\text { Cancer-leukemia, lymphoma, sarcomas } \\
\text { and brain cancer }\end{array}$ & $\begin{array}{l}\text { Cancer (leukemia, lung cancer, } \\
\text { prostate cancer, colon and } \\
\text { pancreatic cancer, ovarian cancer) }\end{array}$ \\
\hline $\begin{array}{l}\text { Neurodevelopmental } \\
\text { and neurobehavioral } \\
\text { effects }\end{array}$ & $\begin{array}{c}\text { Cognitive (mental and psychological development, } \\
\text { memory, language) } \\
\text { Behavioural (attention-deficit hyperactivity disorder, ADHD) } \\
\text { Sensory (visual and auditory stimulation) } \\
\text { Motor (motor skills) } \\
\text { Morphology (physical changes in the brain) }\end{array}$ & $\begin{array}{c}\text { Neurodevelopmental and } \\
\text { neurobehavioural effects }\end{array}$ \\
\hline $\begin{array}{l}\text { Developmental and } \\
\text { reproductive effects }\end{array}$ & $\begin{array}{l}\text { Reproductive problems-spontaneous abortions, stillbirths, } \\
\text { lower birth weights, birth defects and early neonatal deaths }\end{array}$ & n.a. \\
\hline $\begin{array}{l}\text { Immunological } \\
\text { effects }\end{array}$ & $\begin{array}{l}\text { Weakened immune system in special for growing children that } \\
\text { may increase the risk of infectious disease }\end{array}$ & Weakened immune system \\
\hline Endocrine disruption & n.a. ${ }^{1}$ & $\begin{array}{l}\text { Problems of the endocrine glands } \\
\text { (sterility, lowered sperm counts, } \\
\text { cancer of the reproductive organs }\end{array}$ \\
\hline
\end{tabular}

${ }^{1}$ n.a.--not available. 
Table A2. Effects of some pesticides on humans and to the environment [46-49].

\begin{tabular}{|c|c|c|c|c|c|}
\hline Pesticides & $\begin{array}{c}\text { Substance Group/Type } \\
\text { of Pesticides }\end{array}$ & Structure & Actual Status & Effect on Human Health & $\begin{array}{l}\text { Effects on Terrestrial and } \\
\text { Aquatic Biodiversity }\end{array}$ \\
\hline \multirow[t]{6}{*}{ Carbendazim } & \multirow[t]{6}{*}{ Benzimidazole/Fungicide } & & \multirow[t]{6}{*}{$\begin{array}{l}\text { Possible human } \\
\text { carcinogen (according to } \\
\text { USEPA }^{1} \text { ) }\end{array}$} & $\begin{array}{l}\text { May cause genetic defect for } \\
\text { unborn child and for adults may } \\
\text { damage the fertility } \\
\text { (malformed testis) }\end{array}$ & $\begin{array}{c}\text { Manifest teratogenesis } \\
\text { embryotoxicity, infertility and } \\
\text { developmental toxicity for } \\
\text { different mammalian species }\end{array}$ \\
\hline & & & & Hormone disruption & \multirow[t]{3}{*}{ Highly toxic to earthworms } \\
\hline & & & & Foetotoxicity & \\
\hline & & & & $\begin{array}{l}\text { Effects on liver enzyme and kidney } \\
\text { (structural changes, deformation) }\end{array}$ & \\
\hline & & & & $\begin{array}{c}\text { Increase the aromatase activity and } \\
\text { estrogen production }\end{array}$ & \multirow[t]{2}{*}{$\begin{array}{l}\text { Moderately toxic to honeybees } \\
\text { and aquatic organisms }\end{array}$} \\
\hline & & & & $\begin{array}{l}\text { Inhibits the proliferation of human } \\
\text { cancer cell lines, human breast } \\
\text { cancer cells and tumor xenografts }\end{array}$ & \\
\hline \multirow[t]{2}{*}{ Chlorothalonil } & \multirow[t]{2}{*}{ Chloronitrile/Fungicide } & & $\begin{array}{c}\text { Group 2B } \\
\text { (according to IARC) }\end{array}$ & Endocrine issues & $\begin{array}{l}\text { Moderately toxic honeybees, } \\
\text { birds and earthworms }\end{array}$ \\
\hline & & & $\begin{array}{c}\text { Probable human } \\
\text { carcinogen (according to } \\
\text { USEPA) }\end{array}$ & Affect the kidney & Toxic to aquatic organisms \\
\hline \multirow[t]{3}{*}{ Dimethoate } & \multirow{3}{*}{$\begin{array}{l}\text { Organo-phosphate/Insecticide } \\
\text { and Acaricide }\end{array}$} & & \multirow{3}{*}{$\begin{array}{l}\text { Possible human } \\
\text { carcinogen (according to } \\
\text { USEPA) }\end{array}$} & $\begin{array}{l}\text { Possibly a human teratogen } \\
\text { and mutagen }\end{array}$ & \multirow{3}{*}{$\begin{array}{l}\text { Highly toxic to honeybees } \\
\text { and birds } \\
\text { Moderately toxic to } \\
\text { most aquatic } \\
\text { species and earthworms }\end{array}$} \\
\hline & & & & Possible liver toxicant & \\
\hline & & & & Acts as a cholinesterase inhibitor & \\
\hline \multirow[t]{2}{*}{ Azoxystrobin } & \multirow{2}{*}{ Strobilurin/Fungicide } & & \multirow{2}{*}{$\begin{array}{c}\text { Unlikely to present an } \\
\text { acute hazard according } \\
\text { to } \mathrm{WHO}^{2}\end{array}$} & Liver toxicant & \multirow{2}{*}{$\begin{array}{l}\text { Moderately toxic to birds, } \\
\text { honeybees } \\
\text { and aquatic organism }\end{array}$} \\
\hline & & & & $\begin{array}{c}\text { Minor effects on reproduction and } \\
\text { development }\end{array}$ & \\
\hline
\end{tabular}


Table A2. Cont.

Table A3. Effects of some pesticides on humans and to the environment [46-49].

\begin{tabular}{|c|c|c|c|c|c|}
\hline Pesticides & $\begin{array}{c}\text { Substance Group/Type } \\
\text { of Pesticides }\end{array}$ & Structure & Actual Status & Effect on Human Health & $\begin{array}{l}\text { Effects on Terrestrial and } \\
\text { Aquatic Biodiversity }\end{array}$ \\
\hline \multirow[t]{2}{*}{ Chlorpyrifos-methyl } & \multirow[t]{2}{*}{$\begin{array}{c}\text { Organo-phosphate } \\
\text { /Insecticide and Acaricide }\end{array}$} & & \multirow[t]{2}{*}{$\begin{array}{l}\text { Slightly hazardous } \\
\text { according to WHO }\end{array}$} & $\begin{array}{l}\text { Suspected cardiovascular and } \\
\text { blood toxicant }\end{array}$ & $\begin{array}{l}\text { Highly toxic to aquatic } \\
\text { organism }\end{array}$ \\
\hline & & & & Endocrine problems & Moderately toxic to birds \\
\hline \multirow[t]{2}{*}{ Iprodione } & \multirow[t]{2}{*}{ Dicarboximide/Fungicide } & & \multirow{2}{*}{$\begin{array}{c}\text { Probable human } \\
\text { carcinogen (according to } \\
\text { USEPA) }\end{array}$} & $\begin{array}{c}\text { Pulmonary and } \\
\text { endocrine problems }\end{array}$ & Hepatotoxic for mice \\
\hline & & & & $\begin{array}{l}\text { Possible liver, } \\
\text { spleen, adrenals }\end{array}$ & \\
\hline \multirow[t]{2}{*}{ Penconazole } & \multirow[t]{2}{*}{ Triazole/Fungicide } & & \multirow[t]{2}{*}{$\begin{array}{l}\text { Slightly hazardous } \\
\text { (according to WHO) }\end{array}$} & Toxicant for liver & $\begin{array}{c}\text { Toxic for } \\
\text { aquatic organism }\end{array}$ \\
\hline & & & & Endocrine issues & (Zebrafish) \\
\hline \multirow[t]{2}{*}{ Propiconazole } & \multirow[t]{2}{*}{ Triazole/Fungicide } & & $\begin{array}{c}\text { PROBABLE human } \\
\text { carcinogen (according to } \\
\text { USEPA) }\end{array}$ & \multirow[t]{2}{*}{ Toxicant for liver } & \multirow[t]{2}{*}{$\begin{array}{l}\text { Highly toxic for aquatic } \\
\text { organism }\end{array}$} \\
\hline & & & $\begin{array}{c}\text { Unlikely to pose a } \\
\text { hazard for human } \\
\text { health (according to EU) }\end{array}$ & & \\
\hline Thiophanate-methyl & Benzimidazole/Fungicide & & $\begin{array}{c}\text { Probable human } \\
\text { carcinogen (according to } \\
\text { USEPA) }\end{array}$ & Possible liver, kidney toxicant & $\begin{array}{c}\text { Moderately toxic to aquatic } \\
\text { organisms }\end{array}$ \\
\hline Tebuconazole & Triazole/Fungicide & & $\begin{array}{l}\text { Probable human } \\
\text { carcinogen (according to } \\
\text { USEPA) }\end{array}$ & Affect the liver and blood system & $\begin{array}{c}\text { Highly toxic for aquatic } \\
\text { organism }\end{array}$ \\
\hline
\end{tabular}

${ }^{1}$ USEPA—United States Environmental Protection Agency; ${ }^{2}$ WHO—World Health Organization. 


\section{References}

1. Fantke, P.; Juraske, R.; Antón, A.; Friedrich, R.; Jolliet, O. Dynamic multicrop model to characterize impacts of pesticides in food. Environ. Sci. Technol. 2011, 45, 8842-8849. [CrossRef]

2. Gavrilescu, M. Behaviour of persistent pollutants and risks associated with their presence in the environment-Integrated studies. Environ. Eng. Manag. J. 2009, 8, 1517-1531. [CrossRef]

3. Hlihor, R.M.; Gavrilescu, M.; Pogăcean, M.O.; Gavrilescu, M.; Cozma, P.; Simion, I.M.; Rosca, M. Modellling Human Health Risk Generated by the Presence of Pesticides in Vegetable Products. In Modelling Pesticide Dynamics in Vegetable Products and Assessment of Human Health Risks; Hlihor, R.M., Gavrilescu, M., Eds.; Politehnium Publishing House: Iasi, Romania, 2018; pp. 131-191, ISBN 9789736214776.

4. Cara, I.G.; Topa, D.; Calistru, A.E.; Motrescu, I.; Bulgariu, L.; Jităreanu, G. Agri-wastes as a low-cost adsorbent for nicosulfuron herbicide. Environ. Eng. Manag J. 2020, 19, 335-343.

5. De Albuquerque, N.C.P.; Carrão, D.B.; Habenschus, M.D.; De Oliveira, A.R.M. Metabolism studies of chiral pesticides: A critical review. J. Pharm. Biomed. Anal. 2018, 147, 89-109. [CrossRef] [PubMed]

6. Hvězdová, M.; Kosubová, P.; Košíková, M.; Scherr, K.E.; Šimek, Z.; Brodský, L.; Šudoma, M.; Škulcová, L.; Sáňka, M.; Svobodová, M.; et al. Currently and recently used pesticides in Central European arable soils. Sci. Total Environ. 2018, 361-370. [CrossRef]

7. Food and Agriculture Organization of the United States. Pesticides Uses. Available online: http://www.fao. org/faostat/en/\#data/RP (accessed on 17 January 2020).

8. Elibariki, R.; Maguta, M.M. Status of pesticides pollution in Tanzania-A review. Chemosphere 2017, 178, 154-164. [CrossRef]

9. Hlihor, R.M.; Pogăcean, M.O.; Rosca, M.; Cozma, P.; Gavrilescu, M. Modelling the behavior of pesticide residues in tomatoes and their associated long-term exposure risks. J. Environ. Manag. 2019, 233, 523-529. [CrossRef]

10. Pogăcean, M.O.; Hlihor, R.M.; Gavrilescu, M. Monitoring pesticides degradation in apple fruits and potential effects of residues on human health. J. Environ. Eng. Landsc. Manag. 2014, 22, 171-182. [CrossRef]

11. Quijano, L.; Yusà, V.; Font, G.; Pardo, O. Chronic cumulative risk assessment of the exposure to organophosphorus, carbamate and pyrethroid and pyrethrin pesticides through fruit and vegetables consumption in the region of Valencia (Spain). Food Chem. Toxicol. 2016, 89, 39-46. [CrossRef]

12. Łozowicka, B.; Kaczynski, P.; Paritova, C.A.C.E.; Kuzembekova, G.; Abzhalieva, A.; Sarsembayeva, N.; Alihan, K. Pesticide residues in grain from Kazakhstan and potential health risks associated with exposure to detected pesticides. Food Chem. Toxicol. 2014, 64, 238-248. [CrossRef]

13. Finger, R.; Möhring, N.; Dalhaus, T.; Böcker, T. Revisiting pesticide taxation schemes. Ecol. Econ. 2017, 134, 263-266. [CrossRef]

14. Inculet, C.-S.; Mihalache, G.; Sellitto, V.M.; Hlihor, R.M.; Stoleru, V. The effects of a microorganisms-based commercial product on the morphological, biochemical and yield of tomato plants under two different water regimes. Microorganisms 2019, 7, 706. [CrossRef] [PubMed]

15. Kim, K.-H.; Kabir, E.; Jahan, S.A. Exposure to pesticides and the associated human health effects. Sci. Total Environ. 2017, 575, 525-535. [CrossRef]

16. Aksakal, O. Effects of a-cypermethrin pesticide on dna stability and oxidative enzymes in maize (Zea mays). Environ. Eng. Manag. J. 2018, 17, 435-442. [CrossRef]

17. Stoleru, V.; Munteanu, N.; Hura, C.; Sellitto, V.M.; Gavrilescu, M. Organochlorine pesticide residues in soil and edible vegetable. Environ. Eng. Manag. J. 2016, 15, 527-535. [CrossRef]

18. Addi, E.H.A.; Addi, A.A.; Achemchem, F. Evaluation of four pesticides residues contents in the citrus fruits from souss-massa area (morocco). Environ. Eng. Manag. J. 2013, 13, 663-667. [CrossRef]

19. Hlihor, R.-M.; Gavrilescu, M.; Cozma, P.; Rosca, M.; Apostol, L.C. Evaluation of human health risks associated with pesticide dietary intake-An overview on quantitative uncertainty analysis. Environ. Eng. Manag. J. 2018, 17, 2263-2274. [CrossRef]

20. Valcke, M.; Bourgault, M.-H.; Rochette, L.; Normandin, L.; Samuel, O.; Belleville, D.; Blanchet, C.; Phaneuf, D. Human health risk assessment on the consumption of fruits and vegetables containing residual pesticides: A cancer and non-cancer risk/benefit perspective. Environ. Int. 2017, 108, 63-74. [CrossRef]

21. Chen, C.; Qian, Y.; Chen, Q.; Tao, C.; Li, C.; Li, Y. Evaluation of pesticide residues in fruits and vegetables from Xiamen, China. Food Control. 2011, 22, 1114-1120. [CrossRef] 
22. Bakırcı, G.T.; Acay, D.B.Y.; Bakırcı, F.; Otles, S. Pesticide residues in fruits and vegetables from the Aegean region, Turkey. Food Chem. 2014, 160, 379-392. [CrossRef]

23. Food and Agriculture Organization of the United States. Crops and Livestock Product. Available online: http://www.fao.org/faostat/en/\#data/TP (accessed on 17 April 2020).

24. National Phytosanitary Authority. Report on the National Plan for Pesticide Residues Monitoring in Fruit, Vegetables and Cereals, from Internal Production for 2016. Laboratory for Pesticide Residue Control in Plants and Vegetable Products, National Phytosanitary Authority. (In Romanian). Available online: https://www. madr.ro/docs/fitosanitar/reziduuri-pesticide/raport-monitorizare-reziduuri-2016-bucuresti-.pdf (accessed on 10 July 2019).

25. The 2016 European Union report on pesticide residues in food. EFSA J. 2018, 16, e05348. [CrossRef]

26. European Food Safety Authority. Pesticide Residue Control Results National Summary Report. EFSA J. 2016. Available online: http://www.ansvsa.ro/download/pesticide/pesticide_monitorizare/2016-RomaniaSummary-Report-Pesticide-Monitoring.pdf (accessed on 22 November 2020).

27. European Food Safety Authority. EFSA Calculation Model Pesticide Residue Intake Model "PRIMo" Revision 2. Available online: http://www.efsa.europa.eu/en/applications/pesticides/tools (accessed on 20 March 2019).

28. Knežević, Z.; Serdar, M.; Ahel, M. Risk assessment of the intake of pesticides in Croatian diet. Food Control 2012, 23, 59-65. [CrossRef]

29. Łozowicka, B. Health risk for children and adults consuming apples with pesticide residue. Sci. Total Environ. 2015, 502, 184-198. [CrossRef] [PubMed]

30. Board for the Authorization of Plant Protection Products and Biocides. Residues. Risk to Consumers, Version 2. In Evaluation Manual for the Authorisation of Plant Protection Products and Biocides According to Regulation (EC) No 1107/2009-EU Part; pp. 1-17. Available online: https://english.ctgb.nl/ (accessed on 10 March 2019).

31. Héraud, F.; Barraj, L.M.; Moy, G.G. GEMS/Food Consumption Cluster Diets. In Total Diet Studies; Springer: Berlin/Heidelberg, Germany, 2013; pp. 427-434.

32. World Health Organization. WHO Guidelines for the Production, Control and Regulation of Snake Antivenom Immunoglobulins. Available online: https://www.who.int/bloodproducts/snake_antivenoms/ snakeantivenomguide/en/ (accessed on 2 February 2020).

33. European Commission. Pesticides Database. Available online: https://ec.europa.eu/food/plant/pesticides/eupesticides-database/public/?event=homepage\&language $=\mathrm{ENn}$ (accessed on 26 January 2020).

34. Li, Z.-X.; Nie, J.; Yan, Z.; Xu, G.-F.; Li, H.-F.; Kuang, L.-X.; Pan, L.-G.; Xie, H.-Z.; Wang, C.; Liu, C.-D.; et al. Risk assessment and ranking of pesticide residues in Chinese pears. J. Integr. Agric. 2015, 14, 2328-2339. [CrossRef]

35. Szpyrka, E.; Kurdziel, A.; Matyaszek, A.; Podbielska, M.; Rupar, J.; Słowik-Borowiec, M. Evaluation of pesticide residues in fruits and vegetables from the region of south-eastern Poland. Food Control 2015, 48, 137-142. [CrossRef]

36. Łozowicka, B.; Abzeitova, E.; Sagitov, A.; Kaczyński, P.; Toleubayev, K.; Li, A. Studies of pesticide residues in tomatoes and cucumbers from Kazakhstan and the associated health risks. Environ. Monit. Assess. 2015, 187, 609. [CrossRef]

37. Strucinski, P.; Morzycka, B.; Góralczyk, K.; Hernik, A.; Czaja, K.; Korcz, W.; Matuszak, M.; Minorczyk, M.; Łyczewska, M.; Pruss, B.; et al. Consumer risk assessment associated with intake of pesticide residues in food of plant origin from the retail market in Poland. Hum. Ecol. Risk Assess. Int. J. 2015, 21, 2036-2061. [CrossRef]

38. Mebdoua, S.; Lazali, M.; Ounane, S.M.; Tellah, S.; Nabi, F.; Ounane, G. Evaluation of pesticide residues in fruits and vegetables from Algeria. Food Addit. Contam. Part B 2017, 10, 91-98. [CrossRef]

39. Stephenson, C.L.; Harris, C. An assessment of dietary exposure to glyphosate using refined deterministic and probabilistic methods. Food Chem. Toxicol. 2016, 95, 28-41. [CrossRef]

40. Regulation (EU) 2019/1090 - Concerning the Non-Renewal of Approval of the Active Substance Dimethoate in Accordance with Regulation (EC) No 1107/2009 of the European Parliament and of the Council Concerning the Placing of Plant Protection Products on the Market, and Amending the Annex to Commission Implementing Regulation (EU) No 540/2011. Available online: https:/eur-lex.europa.eu/legal-content/EN/TXT/PDF/?uri= CELEX:32019R1090\&from=EN (accessed on 2 February 2020). 
41. Regulation (EC) No 1107/2009 of the European Parliament and of the Council of 21 October 2009 concerning the Placing of Plant Protection Products on the Market and Repealing Council Directives 79/117/EEC and 91/414/EEC. Available online: https://eur-lex.europa.eu/legal-content/EN/TXT/PDF/?uri=CELEX: 32009R1107\&qid=1606728771548\&from=EN (accessed on 2 February 2020).

42. Regulation (EU) 2019/677 of 29 April 2019 Concerning the Non-Renewal of the Approval of the Active Substance Chlorothalonil, in Accordance with Regulation (EC) No 1107/2009 of the European Parliament and of the Council Concerning the Placing of Plant Protection Products on the Market, and Amending Commission Implementing Regulation (EU) No 540/2011. Available online: https://eur-lex.europa.eu/legalcontent/EN/TXT/?uri=uriserv:OJ.L_.2019.114.01.0015.01.ENG (accessed on 2 February 2020).

43. Alavanja, M.C.R.; Bonner, M.R. Occupational pesticide exposures and cancer risk: A review. J. Toxicol. Environ. Health Part B 2012, 15, 238-263. [CrossRef]

44. Muñoz-Quezada, M.T.; Lucero, B.A.; Barr, D.B.; Steenland, K.; Levy, K.; Ryan, P.B.; Iglesias, V.; Alvarado, S.; Concha, C.; Rojas, E.; et al. Neurodevelopmental effects in children associated with exposure to organophosphate pesticides: A systematic review. NeuroToxicology 2013, 39, 158-168. [CrossRef] [PubMed]

45. United Nations Environment Programme. Childhood Pesticide Poisoning. Available online: https://www.who.int/ceh/publications/pestpoisoning.pdf (accessed on 6 April 2020).

46. Food and Agriculture Organization of the United Nations. FAOSpecifications and Evaluations for Agricultural Pesticides-Dimethoate. Available online: http://www.fao.org/fileadmin/templates/agphome/documents/ Pests_Pesticides/Specs/Dimethoate2012_2.pdf (accessed on 20 January 2020).

47. Pesticide Properties Database. Available online: http://sitem.herts.ac.uk/aeru/ppdb/ (accessed on 9 April 2020).

48. International Agency for Research on Cancer. IARC Monographs on the Identification of Carcinogenic Hazards to Humans. Available online: https://monographs.iarc.fr/agents-classified-by-the-iarc/ (accessed on 8 January 2020).

49. Singh, S.; Singh, N.; Kumar, V.; Datta, S.; Wani, A.B.; Singh, D.; Singh, K.; Singh, J. Toxicity, monitoring and biodegradation of the fungicide carbendazim. Environ. Chem. Lett. 2016, 14, 317-329. [CrossRef]

Publisher's Note: MDPI stays neutral with regard to jurisdictional claims in published maps and institutional affiliations.

(C) 2020 by the authors. Licensee MDPI, Basel, Switzerland. This article is an open access article distributed under the terms and conditions of the Creative Commons Attribution (CC BY) license (http://creativecommons.org/licenses/by/4.0/). 